\title{
Corynebacterium ciconiae sp. nov., isolated from the trachea of black storks (Ciconia nigra)
}

\author{
J. F. Fernández-Garayzábal, ${ }^{1}$ A. I. Vela, ${ }^{1}$ R. Egido, ${ }^{1}$ R. A. Hutson, ${ }^{2}$ \\ M. P. Lanzarot, ${ }^{3}$ M. Fernández-García ${ }^{3}$ and M. D. Collins ${ }^{2}$ \\ ${ }^{1}$ Departamento de Sanidad Animal, Facultad de Veterinaria, Universidad Complutense, \\ 28040 Madrid, Spain \\ ${ }^{2}$ School of Food Biosciences, University of Reading, Reading RG6 6AP, UK \\ ${ }^{3}$ Gesnatura S.L., Avda. Brasil, 4, 28020 Madrid, Spain
}

\begin{abstract}
Eight unidentified Gram-positive, rod-shaped organisms were recovered from the tracheas of apparently healthy black storks (Ciconia nigra) and subjected to a polyphasic taxonomic analysis. Based on cellular morphology and biochemical criteria the isolates were tentatively assigned to the genus Corynebacterium, although three of the organisms did not appear to correspond to any recognized species. Comparative $16 \mathrm{~S}$ rRNA gene sequencing studies demonstrated that all of the isolates were phylogenetically members of the genus Corynebacterium. Five strains were genotypically identified as representing Corynebacterium falsenii, whereas the remaining three strains represented a hitherto unknown subline, associated with a small subcluster of species that includes Corynebacterium mastitidis and its close relatives. On the basis of phenotypic and phylogenetic evidence, it is proposed that the unknown isolates from black storks represent a novel species within the genus Corynebacterium, for which the Corynebacterium ciconiae sp. nov. is proposed. The type strain is CECT $5779^{\top}\left(=B S 13^{\top}=\right.$ CCUG $\left.47525^{\top}\right)$.
\end{abstract}

The genus Corynebacterium currently comprises over 50 recognized species, many of which have been described during the last decade. The recognition of large numbers of novel species in recent years has been possible by the use of improved taxonomic methods, such as chemotaxonomic and molecular-based approaches, especially $16 \mathrm{~S}$ rRNA gene sequencing. Many of the novel Corynebacterium species have been isolated from human (e.g. Funke et al., 1997a, c, 1998; Sjödén et al., 1998; Collins et al., 1999b; Renaud et al., 2001) or animal (e.g. Fernández-Garayzábal et al., 1998; Pascual et al., 1998; Collins et al., 1999a, 2001a, b) clinical sources. However, corynebacteria also occur as part of the indigenous flora of animals, although there is little information on the diversity of these corynebacterial species or their host distribution. Several novel Corynebacterium species have been described that may represent inhabitants of the natural microflora of different mucosal surfaces in different animals (Fernández-Garayzábal et al., 2003; Goyache et al., 2003a, b). Here, we have used phenotypic (including chemical markers) and molecular genetic methodologies to characterize several Corynebacteriumlike organisms recovered from the tracheas of wild nestling

Published online ahead of print on 4 June 2004 as DOI 10.1099/ ijs.0.63165-0.

The GenBank/EMBL/DDBJ accession number for the 16S rRNA gene sequence of strain CECT $5779^{\top}$ is AJ555193. black storks (Ciconia nigra). Based on these findings, we propose a novel Corynebacterium species, Corynebacterium ciconiae sp. nov.

During an investigation of the normal flora of the tracheas of healthy nestling black storks, eight unidentified Grampositive, rod-shaped organisms were recovered from different animals. Samples from tracheas were collected with sterile swabs with transport medium and kept under refrigeration until being processed in the laboratory within $6 \mathrm{~h}$. Strains were isolated on Columbia blood agar plates (bioMérieux) and incubated for $24 \mathrm{~h}$ at $37^{\circ} \mathrm{C}$. The strains were biochemically characterized using the API Coryne (version 2.0), API ZYM and API 50CH systems (bioMérieux) according to the manufacturer's instructions. Incubation of the API $50 \mathrm{CH}$ strips was extended up to $72 \mathrm{~h}$, with examination every $24 \mathrm{~h}$. Lipophilic requirements and the CAMP test with Staphylococcus aureus ATCC 25923 were determined according to standard procedures (Funke et al., 1997b). Fatty acid methyl esters were prepared and analysed as described by Kämpfer \& Kroppenstedt (1996). The presence of mycolic acids was investigated by GLC analysis of trimethylsilylated derivatives (TMS-MAME) (Klatte et al., 1994). For 16S rRNA gene sequence analysis, a large fragment (around 1450 bases) of the 16S rRNA gene of the isolates was amplified by PCR and directly sequenced using a Taq DyeDeoxy terminator cycle sequencing kit (Applied Biosystems) and an automatic 
DNA sequencer (model 373A; Applied Biosystems). The closest known relatives of the novel isolates were determined by performing a database search. A phylogenetic tree was constructed according to the neighbour-joining method with the program NEIGHBOR (Felsenstein, 1989). The stability of the groupings was estimated by bootstrap analysis (500 replications) using the programs DNABOOT, DNADIST, NEIGHBOR and CONSENSE (Felsenstein, 1989).

The eight unidentified isolates consisted of Gram-positive, non-motile, non-spore-forming, short rod-shaped cells. When cultured aerobically on Columbia blood agar plates, the isolates formed white (strains BS17, BS26, BS28, BS48 and BS60) or creamy (strains BS2, BS8 and BS13 ${ }^{\mathrm{T}}$ ), small (approximately 1-2 $\mathrm{mm}$ diameter, after $24 \mathrm{~h}$ incubation at $37^{\circ} \mathrm{C}$ ) colonies, which were circular, convex, dry and nonhaemolytic. All isolates were catalase-positive, grew under anaerobic conditions, were non-lipophilic and did not display a positive CAMP reaction with $S$. aureus after $48 \mathrm{~h}$. The isolates did not hydrolyse either gelatin or aesculin, and they did not reduce nitrate. Three strains did not hydrolyse urea (BS2, BS8 and BS13 ${ }^{\mathrm{T}}$ ). All strains produced acid from glucose and ribose, but not from D-xylose, mannitol, lactose, sucrose or glycogen. In addition, isolates $\mathrm{BS} 2, \mathrm{BS} 8$ and $\mathrm{BS}_{13}{ }^{\mathrm{T}}$ produced acid from maltose. All of the strains gave positive reactions for alkaline phosphatase and pyrazinamidase, but no activity was detected for pyrrolidonyl arylamidase, $\beta$-glucuronidase, $\beta$-galactosidase, $\alpha$-glucosidase and $N$-acetyl- $\beta$-glucosaminidase. Two different numerical profiles were obtained with the commercial API Coryne system, 2101304 (strains BS17, BS26, BS28, BS48 and BS60) and $2100324\left(\mathrm{BS} 2, \mathrm{BS} 8\right.$ and $\mathrm{BS} 13^{\mathrm{T}}$ ), which correspond to good and excellent identification within the genus Corynebacterium, respectively. The API Coryne numerical profile 2101304 has also been reported for Corynebacterium falsenii (Sjödén et al., 1998) and the numerical profile 2100324 for Corynebacterium imitans and C. falsenii (Funke et al., 1997a; Fernández-Garayzábal et al., 2003), but the black stork isolates can be easily differentiated from these species based on additional biochemical tests (Table 1). Three isolates (BS2, BS8 and $\mathrm{BS}^{2} 3^{\mathrm{T}}$ ) were biochemically characterized further using the API $50 \mathrm{CH}$ and API ZYM systems. All produced acid from glycerol, D-fructose, D-mannose and $\mathrm{N}$-acetylglucosamine. None of the strains produced acid from erythritol, Larabinose, L-xylose, adonitol, methyl $\beta$-xyloside, galactose, sorbose, L-rhamnose, dulcitol, inositol, sorbitol, methyl $\alpha$-D-mannoside, methyl $\alpha$-D-glucoside, amygdalin, arbutin, salicin, cellobiose, melibiose, inulin, melezitose, D-raffinose, xylitol, $\beta$-gentiobiose, D-turanose, D-lyxose, D-tagatose, D-fucose, D-arabitol, L-arabitol, 2-ketogluconate or 5ketogluconate. Two isolates (BS2 and BS8) produced acid from $\mathrm{D}$-arabinose, $\mathrm{L}$-fucose and gentiobiose, one isolate (BS8) produced acid from starch and another (isolate BS2) formed acid from trehalose. All eight strains gave positive reactions for acid phosphatase, esterase C4, ester lipase C8, lipase C14, naphthol-AS-BI-phosphohydrolase, $\beta$-glucosidase and leucine arylamidase. No activity was detected for $\alpha$-mannosidase, $\alpha$-galactosidase, $\alpha$-fucosidase, chymotrypsin, trypsin, valine arylamidase or cystine arylamidase. The morphological and biochemical characteristics of both groups of strains were consistent with their provisional assignment to the genus Corynebacterium.

To establish the phylogenetic position of the two groups of strains, their 16S rRNA gene sequences were determined by direct sequencing of in vitro-amplified rRNA gene products. The sequences of a large fragment $(>1400 \mathrm{nt})$ of representative strains of each group (BS2, BS13 ${ }^{\mathrm{T}}, \mathrm{BS} 26$ and BS48) and approximately $1000 \mathrm{nt}$ of the other strains were determined. Sequence searches of GenBank revealed that the unknown isolates were phylogenetically representative of members of the genus Corynebacterium (data not shown). The isolates from black storks formed two separate phylogenetic groups consistent with their phenotypic division, with strains displaying 99.8-100\% 16S rRNA gene sequence similarity within their respective groups. The 16S rRNA gene sequence of strains BS26 and BS48 displayed $99 \cdot 1 \%$ similarity to the sequence of $C$. falsenii CCUG $33651^{\mathrm{T}}$. The genotypic identification of isolates BS17, BS26, BS28, BS48 and BS60 as C. falsenii is consistent with the overall results of their phenotypic characteristics. Note that C. falsenii has also been isolated from normal flora of the trachea of healthy eagles (FernándezGarayzábal et al., 2003). These results suggest that this species may represent a normal inhabitant of the natural microflora of the higher respiratory tract of birds.

The second group of strains, as exemplified by strains BS2, BS8 and $\mathrm{BS} 13^{\mathrm{T}}$, was phylogenetically distinct from all previously recognized Corynebacterium species. A tree depicting the phylogenetic relationships of this unidentified bacterium (based on the 16S rRNA gene sequence of strain $\mathrm{BS}^{\mathrm{T}} 3^{\mathrm{T}}$ ) within the genus Corynebacterium is shown in Fig. 1. The unknown organism formed a distinct subline within the genus Corynebacterium, branching proximal to the base of a subcluster of species, that includes Corynebacterium propinquum and Corynebacterium pseudodiphtheriticum as its close relatives. Bootstrap resampling, however, showed that the association of the black stork bacterium with this subcluster of species is not statistically significant and, from the tree construction analysis, it is evident that the unknown organism does not exhibit a significant affinity with any recognized species. The unidentified bacterium displayed highest sequence similarities to Corynebacterium mastitidis CECT $4843^{\mathrm{T}}(94 \cdot 4 \%)$, Corynebacterium durum ICB G15036 ${ }^{\mathrm{T}}(92 \cdot 0 \%)$, Corynebacterium matruchotii CIP $81.82^{\mathrm{T}}(93 \cdot 3 \%)$, C. propinquum CIP $103792^{\mathrm{T}}(94 \cdot 1 \%)$ and C. pseudodiphtheriticum CIP $103420^{\mathrm{T}}(94 \cdot 5 \%)$, with other species showing lower levels of sequence similarity. However, sequence divergence values of $>3 \%$ with recognized corynebacterial species show unequivocally that the black stork bacterium represents a hitherto unknown species (Stackebrandt \& Goebel, 1994). The cellular lipid composition of the unknown black stork bacterium was also examined, as these compounds 
Table 1. Characteristics that differentiate Corynebacterium ciconiae sp. nov. from its closest biochemical and phylogenetic relatives

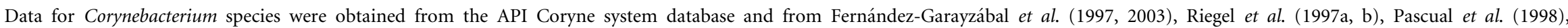

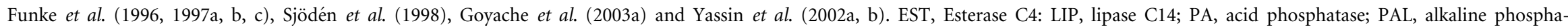

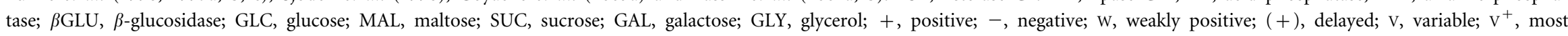
strains positive.

\begin{tabular}{|c|c|c|c|c|c|c|c|c|c|c|c|c|c|c|c|}
\hline \multirow[t]{2}{*}{ Species } & \multirow[t]{2}{*}{ Lipophilism } & \multirow{2}{*}{$\begin{array}{c}\text { CAMP } \\
\text { test }\end{array}$} & \multirow{2}{*}{$\begin{array}{c}\text { Nitrate } \\
\text { reduction }\end{array}$} & \multirow{2}{*}{$\begin{array}{l}\text { Hydrolysis } \\
\text { of urea }\end{array}$} & \multicolumn{5}{|c|}{ Production of: } & \multicolumn{5}{|c|}{ Acid production from: } & \multirow[t]{2}{*}{ Other characteristics } \\
\hline & & & & & EST & LIP & PA & PAL & $\beta G L U$ & GLC & MAL & SUC & GAL & GLY & \\
\hline C. ciconiae sp. nov. & - & - & - & - & + & + & + & + & + & + & + & - & - & + & \\
\hline C. amycolatum & - & - & $+^{*}$ & $-*$ & + & $\mathrm{V}^{+}$ & + & + & - & + & $+^{*}$ & $+^{*}$ & - & - & \\
\hline C. appendicis & + & $\mathrm{ND}$ & - & + & - & - & - & + & - & + & + & - & ND & + & $\begin{array}{l}\text { Ester lipase C8-, naphthol-AS-BI-phosphohydrolase- } \\
\text { and leucine arylamidase-negative }\end{array}$ \\
\hline C. aquilae & - & - & - & - & + & - & + & + & - & + & - & - & + & + & Chymotrypsin-positive \\
\hline C. coyleae & $\mathrm{ND}$ & + & - & - & + & $\mathrm{ND}$ & + & + & - & + & - & - & - & - & $\begin{array}{l}\text { 5-Ketogluconate and cystine arylamidase-positive; } \\
\mathrm{N} \text {-acetyl- } \beta \text {-glucosamine-negative }\end{array}$ \\
\hline C. durum & - & - & + & $\mathrm{V}$ & $\mathrm{ND}$ & $\mathrm{ND}$ & $\mathrm{ND}$ & - & $\mathrm{ND}$ & + & + & + & + & $\mathrm{ND}$ & Mannitol-positive; ribose-negative \\
\hline C. falsenii & - & - & - & $(+)$ & + & + & + & + & - & + & - & - & + & $-\dagger$ & \\
\hline C. imitans & $\mathrm{ND}$ & + & - & - & + & - & + & + & - & + & + & $\mathrm{W}$ & - & - & $\begin{array}{l}\text { Lactose-positive; } N \text {-acetylglucosamine- and leucine } \\
\text { arylamidase-negative }\end{array}$ \\
\hline C. jeikeium & + & - & - & - & $\mathrm{ND}$ & + & $\mathrm{ND}$ & + & ND & + & $-{ }^{\star}$ & - & ND & $\mathrm{ND}$ & \\
\hline C. mastitidis & + & - & - & $\mathrm{V}$ & + & + & + & + & + & - & - & - & ND & $\mathrm{ND}$ & $\begin{array}{l}\text { Ribose-negative; valine arylamidase- and cystine } \\
\text { arylamidase-positive }\end{array}$ \\
\hline C. matruchotii & - & - & + & $-*$ & $\mathrm{ND}$ & $\mathrm{ND}$ & $\mathrm{ND}$ & - & ND & + & + & $+^{*}$ & - & $\mathrm{ND}$ & \\
\hline C. minutissimum & - & - & - & - & - & - & - & + & - & + & + & $+^{*}$ & ND & - & Ribose-, mannose- and ester lipase C8-negative \\
\hline C. phocae & ND & $\mathrm{ND}$ & - & $\mathrm{V}$ & - & - & + & + & - & + & + & $\mathrm{V}$ & - & - & D-Fructose- and $\alpha$-glucosidase-positive \\
\hline C. propinquum & - & - & + & - & $\mathrm{ND}$ & $\mathrm{ND}$ & $\mathrm{ND}$ & $\mathrm{v}$ & ND & - & - & - & ND & $\mathrm{ND}$ & \\
\hline C. pseudodiphtheriticum & - & - & + & + & $\mathrm{ND}$ & $\mathrm{ND}$ & $\mathrm{ND}$ & $\mathrm{v}$ & ND & - & - & - & ND & $\mathrm{ND}$ & \\
\hline C. spheniscorum & - & + & - & - & + & - & - & - & - & + & + & - & - & - & Naphthol-AS-BI-phosphohydrolase-negative \\
\hline C. striatum & - & $\mathrm{v}$ & $+^{*}$ & - & $\mathrm{ND}$ & $\mathrm{ND}$ & ND & + & ND & + & $-{ }^{*}$ & $+^{*}$ & $\mathrm{~V}$ & $\mathrm{ND}$ & \\
\hline
\end{tabular}

*Variable, according to Funke et al. (1997b).

$\dagger$ Positive according to Fernández-Garayzábal et al. (2003). 


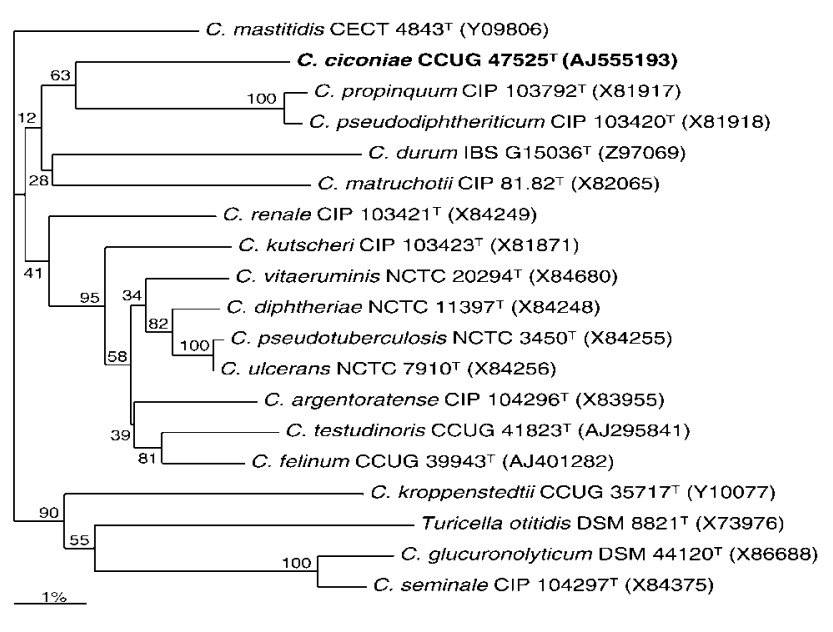

Fig. 1. Unrooted tree based on $16 \mathrm{~S}$ rRNA gene sequences showing the phylogenetic relationships of Corynebacterium ciconiae sp. nov. Bootstrap values (expressed as percentages of 500 replications) are given at branching points. Bar, $1 \%$ sequence divergence.

have been shown to be taxonomically useful markers for the Corynebacterium group of organisms. Analysis of a representative strain, BS13 ${ }^{\mathrm{T}}\left(=\mathrm{CECT} 5779^{\mathrm{T}}\right)$, revealed the absence of corynomycolic acids. The absence of mycolic acids was confirmed by analysing concentrated extracts followed by high-temperature GLC. Examination of the long-chain cellular fatty acids of this strain showed the presence of straight-chain saturated $\mathrm{C}_{14: 0}(0 \cdot 6 \%), \mathrm{C}_{15: 0}$ $(0 \cdot 6 \%), \mathrm{C}_{16: 0}(36 \cdot 2 \%), \mathrm{C}_{17: 0}(1 \cdot 1 \%), \mathrm{C}_{18: 0}(18 \cdot 7 \%)$, $\mathrm{C}_{20: 0}(0 \cdot 8 \%)$ and monounsaturated cis-9 $\mathrm{C}_{18: 1}(42 \cdot 2 \%)$, consistent with its phylogenetic assignment to the genus Corynebacterium.

It is evident from the presented findings that the Grampositive, rod-shaped strains recovered from the trachea of black storks could be divided into two groups, one of which corresponded to $C$. falsenii. The second group of strains, although exhibiting overall cellular morphological and biochemical characteristics consistent with the genus Corynebacterium, did not appear to conform to any recognized species. Phylogenetic analysis based on 16S rRNA gene sequencing confirmed this provisional assignment and clearly demonstrated the unidentified black stork bacterium represents an unknown subline within the genus Corynebacterium. Despite its phylogenetic affinity with true corynebacteria, the black stork bacterium is somewhat unusual in not synthesizing corynomycolic acids. These $\alpha$-alkyl- $\beta$-hydroxylated long-chain fatty acids (length 22-36 carbons) were considered to be highly characteristic of the genus Corynebacterium, but it is now recognized that several authentic species of this genus (e.g. Corynebacterium amycolatum, Corynebacterium kroppenstedtii, Corynebacterium atypicum) lack these unusual lipids. Biochemical data also provide support for distinctiveness of the black stork bacterium. Biochemically, the unknown bacterium can easily be differentiated from the most closely phylogenetically related and other biochemically similar Corynebacterium species (Table 1). Based on both phenotypic and phylogenetic evidence, we consider the isolates from the trachea of nestling black storks merit classification as a novel species within the genus Corynebacterium, for which the name Corynebacterium ciconiae sp. nov. is proposed.

\section{Description of Corynebacterium ciconiae sp. nov.}

Corynebacterium ciconiae [ci.co' ni.ae. L. gen. fem. n. ciconiae of a (black) stork].

Cells are Gram-positive, non-spore-forming, non-motile rods. Colonies are creamy-white, circular, convex, dry and approximately $1-2 \mathrm{~mm}$ in diameter on Columbia blood agar after $24 \mathrm{~h}$ incubation at $37^{\circ} \mathrm{C}$. Colonies are nonhaemolytic. Facultatively anaerobic. Non-lipophilic, and CAMP-negative with S. aureus. Aesculin, gelatin and urea are not hydrolysed. Nitrate is not reduced. Acid is produced from glucose, ribose, glycerol, D-fructose, Dmannose, $N$-acetyl- $\beta$-glucosamine and maltose, but not from D-xylose, mannitol, lactose, sucrose, glycogen, erythritol, L-arabinose, L-xylose, adonitol, methyl $\beta$-xyloside, galactose, sorbose, L-rhamnose, dulcitol, inositol, sorbitol, methyl $\alpha$-D-mannoside, methyl $\alpha$-D-glucoside, amygdalin, arbutin, salicin, cellobiose, melibiose, inulin, melezitose, D-raffinose, xylitol, $\beta$-gentiobiose, D-turanose, D-lyxose, Dtagatose, D-fucose, D-arabitol, L-arabitol, 2-ketogluconate or 5-ketogluconate. Acidification of D-arabinose, L-fucose, trehalose, starch and gentiobiose is variable. Activity for alkaline and acid phosphatases, ester lipase C8, esterase C4, lipase C14, naphthol-AS-BI-phosphohydrolase, leucine arylamidase, $\beta$-glucosidase and pyrazinamidase is detected. Pyrrolidonyl arylamidase, $\beta$-glucuronidase, $\beta$-galactosidase, $\alpha$-glucosidase, $N$-acetyl- $\beta$-glucosaminidase, $\alpha$-mannosidase, $\alpha$-galactosidase, $\alpha$-fucosidase, chymotrypsin, trypsin, valine arylamidase and cystine arylamidase are not produced. Mycolic acids are absent. Long-chain fatty acids are of the straight-chain saturated and monounsaturated types, with $\mathrm{C}_{16: 0}$ and cis-9 $\mathrm{C}_{18: 1}$ predominating.

The type strain, CECT $5779^{\mathrm{T}}\left(=\mathrm{BS} 13^{\mathrm{T}}=\right.$ CCUG $\left.47525^{\mathrm{T}}\right)$, was isolated from the trachea of apparently healthy wild nestling black storks (Ciconia nigra).

\section{Acknowledgements}

We thank A. Casamayor for her technical assistance, C. Ballesteros for primary isolation of the black stork isolates and Consejería de Medio Ambiente de la Comunidad de Madrid for permission and help to collect the samples.

\section{References}

Collins, M. D., Hoyles, L., Lawson, P. A., Falsen, E., Robson, R. L. \& Foster, G. (1999a). Phenotypic and phylogenetic characterization of 
a new Corynebacterium species from dogs: description of Corynebacterium auriscanis sp. nov. J Clin Microbiol 37, 3443-3447.

Collins, M. D., Bernard, K. A., Hutson, R. A., Sjödén, B., Nyberg, A. \& Falsen, E. (1999b). Corynebacterium sundsvallense sp. nov., from human clinical specimens. Int J Syst Bacteriol 49, 361-366.

Collins, M. D., Hoyles, L., Foster, G., Sjödén, B. \& Falsen, E. (2001a). Corynebacterium capitovis sp. nov., from a sheep. Int J Syst Evol Microbiol 51, 857-860.

Collins, M. D., Hoyles, L., Hutson, R. A., Foster, G. \& Falsen, E. (2001b). Corynebacterium testudinoris sp. nov., from a tortoise, and Corynebacterium felinum sp. nov., from a Scottish wild cat. Int J Syst Evol Microbiol 51, 1349-1352.

Felsenstein, J. (1989). PHYLIP - Phylogeny inference package (version 3.2). Cladistics 5, 164-166.

Fernández-Garayzábal, J. F., Collins, M. D., Hutson, R. A., Fernandez, E., Monasterio, R., Marco, R. \& Domínguez, L. (1997). Corynebacterium mastitidis sp. nov., isolated from milk of sheep with subclinical mastitis. Int J Syst Bacteriol 47, 1082-1085.

Fernández-Garayzábal, J. F., Collins, M. D., Hutson, R. A., González, I., Fernández, E. \& Domínguez, L. (1998). Corynebacterium camporealensis sp. nov., associated with subclinical mastitis in sheep. Int J Syst Bacteriol 48, 463-468.

Fernández-Garayzábal, J. F., Egido, R., Vela, A. I., Briones, V., Collins, M. D., Mateos, A., Hutson, R. A., Domínguez, L. \& Goyache, J. (2003). Isolation of Corynebacterium falsenii and description of Corynebacterium aquilae sp. nov., from eagles. Int J Syst Evol Microbiol 53, 1135-1138.

Funke, G., Lawson, P. A., Bernard, K. A. \& Collins, M. D. (1996). Most Corynebacterium xerosis strains identified in the routine clinical laboratory correspond to Corynebacterium amycolatum. J Clin Microbiol 34, 1124-1128.

Funke, G., Efstratiou, A., Kuklinska, D., Hutson, R. A., De Zoysa, A., Engler, K. H. \& Collins, M. D. (1997a). Corynebacterium imitans sp. nov. isolated from patients with suspected diphtheria. J Clin Microbiol 35, 1978-1983.

Funke, G., von Gravenitz, A., Clarridge, J. A., III \& Bernard, K. A. (1997b). Clinical microbiology of coryneform bacteria. Clin Microbiol Rev 10, 125-159.

Funke, G., Ramos, C. P. \& Collins, M. D. (1997c). Corynebacterium coyleae sp. nov., isolated from human clinical specimens. Int J Syst Bacteriol 47, 92-96.
Funke, G., Osorio, C. R., Frei, R., Riegel, P. \& Collins, M. D. (1998). Corynebacterium confusum sp. nov., isolated from human clinical specimens. Int J Syst Bacteriol 48, 1291-1296.

Goyache, J., Vela, A. I., Collins, M. D. \& 7 other authors (2003a). Corynebacterium spheniscorum sp. nov., isolated from the cloacae of wild penguins. Int J Syst Evol Microbiol 53, 43-46.

Goyache, J., Ballesteros, C., Vela, A. I. \& \& 7 other authors (2003b). Corynebacterium sphenisci sp. nov., isolated from wild penguins. Int J Syst Evol Microbiol 53, 1009-1012.

Kämpfer, P. \& Kroppenstedt, R. M. (1996). Numerical analysis of fatty acid patterns of coryneform bacteria and related taxa. Can J Microbiol 42, 989-1005.

Klatte, S., Kroppenstedt, R. M. \& Rainey, F. A. (1994). Rhodococcus opacus sp. nov., an unusual nutritionally versatile Rhodococcus species. Syst Appl Microbiol 17, 355-360.

Pascual, C., Foster, G., Alvarez, N. \& Collins, M. D. (1998). Corynebacterium phocae sp. nov., isolated from the common seal (Phoca vitulina). Int J Syst Bacteriol 48, 601-604.

Renaud, F. N. R., Aubel, D., Riegel, P., Meugnier, H. \& Bollet, C. (2001). Corynebacterium freneyi sp. nov., $\alpha$-glucosidase-positive strains related to Corynebacterium xerosis. Int J Syst Evol Microbiol 51, 1723-1728.

Riegel, P., Ruimy, R., Renaud, F. N. R., Freney, J., Prevost, G., Jehl, F., Christen, R. \& Monteil, H. (1997a). Corynebacterium singulare sp. nov., a new species for urease-positive strains related to Corynebacterium minutissimum. Int J Syst Bacteriol 47, 1092-1096.

Riegel, P., Heller, R., Prevost, G., Jehl, F. \& Monteil, H. (1997b). Corynebacterium durum sp. nov., from human clinical specimens. Int J Syst Bacteriol 47, 1107-1111.

Sjödén, B., Funke, G., Izquierdo, A., Akervall, E. \& Collins, M. D. (1998). Description of some coryneform bacteria isolated from human clinical specimens as Corynebacterium falsenii sp. nov. Int J Syst Bacteriol 48, 69-74.

Stackebrandt, E. \& Goebel, B. M. (1994). Taxonomic note: a place for DNA-DNA reassociation and $16 \mathrm{~S}$ rRNA sequence analysis in the present species definition in bacteriology. Int J Syst Bacteriol 44, 846-849.

Yassin, A. F., Steiner, U. \& Ludwig, W. (2002a). Corynebacterium aurimucosum sp. nov. and emended description of Corynebacterium minutissimum Collins and Jones (1983). Int J Syst Evol Microbiol 52, 1001-1005.

Yassin, A. F., Steiner, U. \& Ludwig, W. (2002b). Corynebacterium appendicis sp. nov. Int J Syst Evol Microbiol 52, 1165-1169. 